\title{
Ethnomathematics Perspective and Challenge as a Tool of Mathematical Contextual Learning for Indigenous People
}

\author{
1,2Andi Saparuddin Nur, ${ }^{2}$ Stevanus Budi Waluya, ${ }^{2}$ Kartono, ${ }^{2}$ Rochmad \\ ${ }^{1}$ Mathematics Education, Universitas Musamus, Jl. Kamizaun Mopah Lama, Merauke, Indonesia \\ ${ }^{2}$ Mathematics Education, Universitas Negeri Semarang, Jl. Kelud Utara III, Semarang, Indonesia \\ e-mail: andisaparuddin@students.unnes.ac.id
}

\begin{abstract}
Indigenous people have a very strong connection with culture. The national curriculum needs to provide a place for student learning in indigenous people. Mathematics as knowledge applied in daily life activities becomes relevant to the culture of indigenous people. The purpose of this study is to obtain an overview related to the perspective and challenge of ethnomathematics as a contextual learning mathematics framework for indigenous people. This research is a qualitative study with an ethnographic approach and is carried out on Ammatoa indigenous people, Tana Toa Village, Kajang District, Bulukumba Regency, South Sulawesi Province. The data sources in this study were the head of the Tana Toa village, the tribal chief of Ammatoa, and the teacher in the indigenous territories. Data collection is done through observation, in-depth interviews, literature studies, and document analysis. The results of this study indicate the association of Ammatoa culture with mathematical content which includes knowledge systems, traditional activities, and cultural artifacts. Domains of school mathematics content related to Ammatoa culture include; the concept of number, geometry, comparison, sequence and series, as well as probability and combinatorics. Mathematics learning in Ammatoa indigenous people needs to consider aspects of culture that involve collaborative involvement.
\end{abstract}

Keywords: contextual learning, ethnomathematics, indigenous people

How to Cite: Nur, A. S., Waluya, S. B., Kartono, Rochmad. (2021). Ethnomathematics Perspective and Challenge As a Tool of Mathematical Contextual Learning for Indigenous People. International Journal on Emerging Mathematics Education, 5(1), 1-12. http://dx.doi.org/10.12928/ijeme.v5i1.17072

\section{INTRODUCTION}

Indonesia is the largest archipelago country in the world, with a very complex cultural and ethnic diversity. Culture in Indonesian society is an identity, a perspective, and a structure of knowledge that has been passed down from generation to generation. The Indonesian government seeks to preserve culture through Law Number 5 of 2017 concerning the promotion of culture by increasing the resilience and contribution of Indonesian people's culture to world civilization (MOEC, 2017). The government's effort to integrate culture into formal education through Permendikbud number 20 of 2018 is related to strengthening character education in formal education units by involving educational centers; family, school, and community and apply a class-based approach, school culture, and community (MOEC, 2018).

Culture significantly influences the behavior and way of thinking of people who still maintain the tradition. Community groups that still maintain the culture in every day-to-day activity are indigenous people who generally severely limit communication with the outside world. Culture covers various aspects of life including communication, attitudes, ethics, beliefs, values, and art (Laurens et al., 2019). The 
development of modernization is very rapid to cause cultural preservation is very important, especially in indigenous people.

Formal education has an important role in maintaining cultural preservation through learning that accommodates the context of community life. The national curriculum cannot be applied without regard to the historical, political, and sociocultural aspects of indigenous people (Fouze \& Amit, 2018a; Gavarrete, 2015; Rosa \& Orey, 2018). Paying attention to the cultural aspects of indigenous people in the curriculum is the main key to ensuring the success of formal education while ensuring the preservation and promotion of culture. Culture has an important role in the success of learning (Entremont, 2015), minimizing prejudice towards indigenous people (Gavarrete, 2015), bringing students closer to contextual issues (Nur et al., 2020), and means of student interaction to connect with the student's school environment (Hunter et al., 2016). The phenomenon that occurs in communities related to the fading of cultural identity is a challenge in education, especially in local communities that still uphold customs and traditions.

The process of learning mathematics cannot be separated from the characteristics of interactions that students have with their social environment. Mathematics learning builds students' logical reasoning and attitude and prepares students to be able to implement mathematics in everyday life (Nur et al., 2020). However, most students have not been able to understand mathematics as an integrated system with its application in everyday life (Weldeana, 2016). Mathematics teachers need knowledge related to the socio-cultural conditions where they teach to understand the way of thinking and the initial knowledge possessed by their students. Each student brings their mathematical knowledge, in addition to formal knowledge taught at school so it is important to utilize the cultural context of students in learning mathematics (Entremont, 2015). Various studies in the development of a culturebased mathematics curriculum have been carried out with results that indicate openness, mutual respect, and achievement of mathematics achievement especially in students with very strong cultures (Entremont, 2015; Hunter et al., 2016; Nutti, 2016; Weldeana, 2016).

Ethnomathematics is a field that involves the integration of informal mathematics in cultural contexts for ideas related to school mathematics (Weldeana, 2016). Ethnomathematics as a basic theory to reduce the exclusion of indigenous people through the exploration of cultural diversity in the context of mathematics education (Gavarrete, 2015). Ethnomathematics challenges arise from efforts to find and understand mathematical contexts in cultural ideas and interpretations of local communities (Rosa \& Orey, 2018). Ethnomathematics is a solution that can bridge the concept of formal mathematics with the cultural diversity of indigenous people.

Many abstract designs could be found in the culture of indigenous people related to mathematical content (Weldeana, 2016). Ethnomathematics provides a means to connect mathematics with cultural realities in students' environments. The use of mathematical operational concepts using knowledge systems that already exist in indigenous cultures such as the vigesimal numbers used by the Maya (Moramay \& Méndez, 2010) can be used to minimize the ambiguity of students learning mathematical concepts. Using cultural artifacts such as image mapping and navigation in the marshal island community has close relevance to ethnomathematics content (Ascher, 1995). Unique geometric patterns can also be found in the Evenk Tribe which is evidence that indigenous people have certain ways of expressing abstract symbols (Khoroshikh \& Sergievich, 2019). Some school mathematics content can also be

IJEME, Vol. 5, No. 1, March 2021, 1-12. 
obtained through folklore (Fouze \& Amit, 2018b; Waziri et al., 2010). Combinatoric concepts are also found in Malay culture in classical manuscripts that exemplify probabilistic ways of thinking (Ismail \& Ismail, 2010). This is related to the arrangement of object sets with certain rules. The concept of the geometry of transformation in Papua New Guinea (Were, 2003). Object arrangement patterns are also found in the Moluccas, namely the use of geometric patterns in woven crafts and the grouping of goods sold on local fruits (Laurens et al., 2019). Knowledge systems related to forecasting are also found in the culture of Malagasy people who are connected with the concept of symbolic logic (Ascher, 1997). This fact shows that the local culture contributes informally to mathematical knowledge and has helped the community to deal with various natural phenomenon problems.

Contextual learning is a means to provide meaningful knowledge to students by relating it to real-world situations. Contextual learning offers a strong connection between mathematical content and the context of cultural activities. Ethnomathematics is an idea of knowledge that connects mathematical concepts with everyday life and provides the possibility of a more harmonious relationship with human behavior and the natural surroundings. Learning that draws close to contextual problems provides meaningful understanding and contributes to students' curiosity in learning mathematics (Johnson, 2017). Problem-solving requires situational, cultural, and conceptual contextualization of students (Yee \& Bostic, 2014). Contextual problems provide greater opportunities for students to write mathematical sentences and be able to understand them meaningfully (Johnson, 2017). Culture is an essential contextual part of indigenous people, so it becomes a useful tool to bridge formal mathematics with real problems in the surrounding environment. Mathematics is no longer assumed in a vacuum that has minimal application, but rather as an object that is very closely related to the practice of daily life, including the activities of indigenous people.

The background described above motivates to investigate the challenges of learning mathematics in indigenous people and the perspective ethnomathematics as a tool of contextual learning for indigenous people.

\section{RESEARCH METHOD}

This type of research is a qualitative descriptive study by the snapshot of the ethnographic side at various viewpoint of cultural events. Ethnography is an in-depth study of behavior that occurs naturally in a culture or an entire social group that seeks to understand the relationship between culture and behavior, beliefs, values, concepts, practices, and attitudes of certain groups of people and interpret the reasons (Ary et al., 2010). The focus of this research is the exploration of various Ammatoa cultures related to school mathematics content and the challenges of learning in the classroom.

The place of this research was conducted in the Ammatoa traditional area, Kajang District, Bulukumba Regency, South Sulawesi Province in April to October 2020. At the time of conducting this research, several places in the customary area were quarantined due to the pandemic coronavirus disease 19 (COVID 19) so that some respondents could only be confirmed through virtual communication. Data sources in this study are the head of the Tana Toa village, the tribal chief of Ammatoa and the teacher with more than 20 years of teaching experience in the indigenous Ammatoa community as respondents who represent information related to the cultural perspectives. Data is collected through direct interviews according to health protocols and information elaboration through virtual communication. 
Data collection techniques in this research were carried out through observation, in-depth interviews, literature studies, and document analysis. Observations were made by observing the activities of the Ammatoa indigenous people. At the time of the research, schools had been closed from the teaching and learning process so that information related to classroom learning was obtained through interviews. Documentation is not done through taking pictures or recording videos as a form of respect for local cultural values that are maintained in the Ammatoa customary area. In-depth interviews were conducted to verify, build meaning, and clarify related research findings that could not be revealed through observation. Interviews focused on aspects that could reveal the daily activities of the Ammatoa indigenous people related to mathematics, explore ethnomathematics contained in the culture of Ammatoa indigenous people, and efforts to preserve the culture and the challenges of learning in the classroom. Literature studies are used to strengthen the arguments that have been obtained through comparative, associative, and descriptive studies of the structure of theory or relevant research results (Darmayasa, 2018). Document analysis is carried out to produce credible and transparent research reports through the data validity testing process.

\section{RESULTS AND DISCUSSION}

\section{Brief description of Ammatoa indigenous people}

Some communities that still adhere to customs and cultural principles exclusively in Indonesia are the Ammatoa or Kajang Le'leng who is a group within the Makassar Tribe. The Ammatoa indigenous people inhabit an area in Tana toa Village, Kajang District, Bulukumba Regency, South Sulawesi Province. The Ammatoa people inhabit the customary area in the village of Tana Toa which consists of seven hamlets. The Ammatoa community is an indigenous group that still preserves the forest through the concept of customary conservation and adopts a simple life and closes itself from all forms of modernization (Sambu, 2016), with the customary leader having the title Ammatoa. Common characteristics found in Ammatoa are black clothing, houses made entirely of wood, and no use of modern technology. The principle of the life of the Ammatoa community is kamase-mase (simple life) which is practiced by not using excessive natural resources and rejecting all the conveniences offered by modernization. Indigenous people are prohibited from cutting down forests, digging wells too deep, damaging the environment, violating moral norms, and other restrictions that will bring disaster. Violations committed by the community will be subject to custom punishment. This customary system is a source of unwritten law that binds all Ammatoa people.

\section{The challenges of formal education in the Ammatoa indigenous people}

At present formal education has reached children in indigenous areas with the establishment of two primary schools, and one junior high school in the village of Tana Toa. The most common challenges of formal education in indigenous people are differences in understanding related to systems of knowledge, values, ethics, and prejudice (Gavarrete, 2015; Hunter et al., 2016; Rosa \& Orey, 2018). Transformative and accommodative efforts have appeared in several sectors, all parties trying to find the ideal meeting point. For example, elementary school uniforms as in general schools in Indonesia are red and white uniforms, but in the belief of the Ammatoa indigenous people, the red color is a color that is prohibited from being used in traditional areas. Therefore, the school through the local government provides a 
solution in the form of the use of black and white uniforms on indigenous students and is approved by Ammatoa so that making elementary schools in the Ammatoa indigenous region as the only one who uses uniforms different from other schools in Indonesia.

The practice of learning in the classroom is also very concerned about the characteristics of local culture. Respect is not only seen from the act of greeting each other but involving various cultures of indigenous people in pedagogical practices is a form of respect that can foster love, mutual ownership and eliminate all forms of prejudice (Hunter et al., 2016). The shifting of the traditional paradigm of the Ammatoa indigenous people gave rise to economic problems that required livelihoods outside the customary area. Many students' parents work as harvest laborers or work in plantations that are located very far from the traditional area. School-age children often have to help parents and leave classes for weeks. Even though they don't go with their parents, there is still a lack of supervision of children's learning at home because they only live with the elderly. Student participation in indigenous people regarding school attendance is largely determined by the attention and support of parents (Baxter \& Meyers, 2019). School attendance is an important factor and prerequisite for successful learning. Increasing student participation in-class learning is a challenge for every teacher. Schools need to improve a more harmonious relationship with indigenous people through collaborative learning (Nisser, 2017).

Another problem is the absence of electricity facilities in the customary area so that students find it difficult to find electronic learning sources and lighting is very limited at night. The absence of modern facilities within the customary area is the implication of the traditional system that has been preserved for generations. This causes the Ammatoa community to be very close to the environment and have a very strong conservation philosophy (Sambu, 2016), but it has an impact on student access to school.

A familial approach can eliminate psychological barriers between teachers and students to provide openness to problems that might be encountered in the cultural context of indigenous people. Linking indigenous cultures and incorporating them into the curriculum can bring the distance between schools and students closer (Hunter et al., 2016). Kinship also provides hope for the growth of mutual respect which results in higher student participation in pursuing formal education. Informal learning can be an alternative solution for teachers to reduce limitations in the classroom. Teachers can utilize school-based learning environment to gain deeper knowledge related to student activities and involve more roles of parents and community (Nisser, 2017).

The development of modernization which is increasingly unavoidable, raises the concern of indigenous stakeholders, especially the customary head of Ammatoa in addressing the presence of formal education. Instead of considering formal education as a threat, Ammatoa gives great attention to access to education for students in indigenous areas. Collaborative efforts between schools and indigenous people to bridge the challenges of formal education are currently being established. The teacher and the students' parents make a family gathering and become a means of gathering to provide information on student learning progress. This activity even makes it easier for teachers to track the whereabouts of students who do not attend class learning. However, the communication space has not been maximized and is experiencing obstacles due to the livelihoods of parents of students who are relatively far from the customary area. School communication with traditional stakeholders is also 
established through the participation of teachers in various traditional ceremonial rituals that allow for interaction related to the development of student learning progress. However, this communication has not yet produced a real picture of the progress of student learning development specifically related to attendance issues. The main problem that constrains teachers is the presence of students which may be caused by internal family constraints or community support. Teachers need to pursue learning breakthroughs that can reactivate students to school and convince parents of the importance of formal education.

\section{Exploration of ethnomatematics in Ammatoa indigenous people' culture}

Indigenous people have a lifestyle that is tied to the cultural system. Each member of an indigenous community carries out activities based on conventional unwritten rules but has a strong influence and customary consequences if they violate them. Many indigenous people's activities are inseparable from cultural processes in the form of knowledge systems or artifacts. The national curriculum sometimes ignores the cultural aspects of indigenous people in classroom learning (Gavarrete, 2015; Orey \& Rosa, 2006).

The learning of mathematics in indigenous people is an ecocultural pedagogic act that includes an understanding of culture, language, social identity, and selfregulation (Owens, 2012). The lack of teacher knowledge related to the culture of indigenous people raises a variety of pedagogical practices. More equitable pedagogic practices for indigenous people can be pursued through various approaches, including mutual respect, kinship, and language (Hunter et al., 2016). Language is a factor that determines the success of students studying mathematics (Were, 2003). Terms that are too formal and not related to contextual problems cause learning to be meaningless to students (Johnson, 2017). Students have mathematical thinking identity influenced by social context and cultural identity and self-regulation (Owens, 2012). Understanding the characteristics of students' mathematical thinking can help teachers design contextual and meaningful learning. Modeling is an important part for students to understand various applications of mathematics in cultural contexts (Rosa \& Orey, 2018). The development of culture-based mathematics learning can be done by considering the systems of knowledge, activities, and cultural products of indigenous people included in the curriculum (Gavarrete, 2015).

Ammatoa are known to various traditional rituals such as andingingi, a traditional ceremony aimed at cooling the world, a'nganro, a prayer ritual offered by Ammatoa to obtain pasang (messages) from ancestors, ammenteng a'je'ne, which is one of the Ammatoa election series, as well as rituals at traditional wedding events. Andingingi is a traditional ritual using a variety of offerings placed in a woven palm leaf container. The woven pattern on the container forms a rhombic geometric ornament. The container for water at the event uses gumbang and the place for food or natural products uses bakulu. The illustration of bakulu and gumbang are described in the Figure 1. The materials used in traditional rituals all use traditional tools and all come from nature. The equipment used must not use iron, machinery, and other modern tools as a reminder that humans initially only relied on nature to survive. The philosophical meaning is very profound and provides conservation knowledge to every Ammatoa community. 


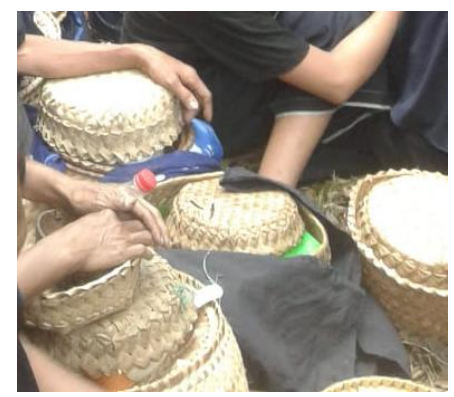

(a)

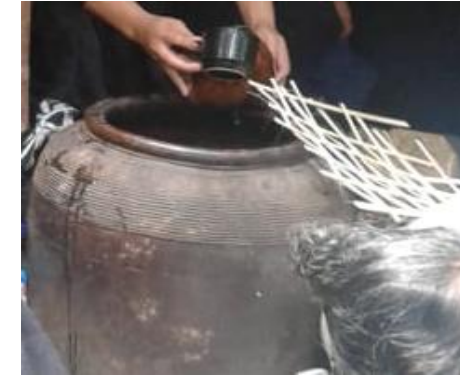

(b)

Figure 1. (a) Bakulu, (b) Gumbang

Other traditional rituals such as commemorating the death of people who have died. Starting from the first day, third, seventh, tenth, until the hundredth day. The process of counting the days is carried out by one of the children in the family member and uses a tool called pappoto'. Ammenteng a'je'ne is one of the most important set of customs because it is related to the election of Ammatoa. One can become Ammatoa if the natural selection process has chosen it. It is the belief of indigenous people that $t u$ rie a'ra'na (the creator) has the authority to determine the person who will lead them. In the Ammatoa selection process, only a few people who belonged to the descendants of tau lima, tau annang, and tau kintara were entitled to participate in the traditional ritual. This traditional ritual process allows the emergence of combinatoric and probabilistic concepts. Each candidate has the same opportunity to become an Ammatoa, depending on the ability to complete customs rituals until completion.

The Ammatoa are familiar with traditional leadership structures for generations. In carrying out affairs within the customary area, Ammatoa is assisted by several gallarang. Gallarang is an important position because it is Ammatoa's assistant in handling various matters. In agriculture, a gallarang named gallarang pantama can determine the time to enter the planting period, the harvest period, and the dry season by using signs that are shown by nature. There is a Gallarang Lambo who is a facilitator between Ammatoa and outside communities in the customs area. Every person who enters the customary area must first obtain Gallarang Lambo approval.

The Ammatoa indigenous people believe that the beginning of life originates in the dark mother's womb and will return to the dark land. Therefore, life in the world is only an intermediate between the womb and the dark grave, so that the clothes that are used are all black as a symbol that the Ammatoa people must not forget the dark womb and the grave. Black is a color that has a very deep philosophical meaning and is an interpretation of the way of life of the Ammatoa indigenous people who carry out the kamase-mase nature (simple life). All clothes that are used are made by themselves using traditional looms. Clothing material is made of cotton yarn and given a black dye on clothes obtained on the leaves of plants in the custom area. The available materials must be optimized because nothing should be wasted. To be able to produce handicraft weaving such as sarong requires an exact calculation related to the availability of material and time. The cultural expression of the Ammatoa community in the form of traditional dance is Pabitte Pasappu. This dance is a cultural expression that symbolizes the prohibition of cockfighting in the customary area. The Ammatoa component are illustrated in Figure 2. 


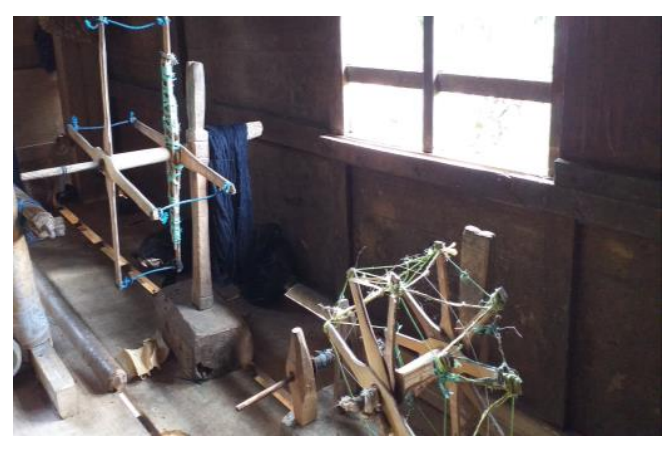

(a)

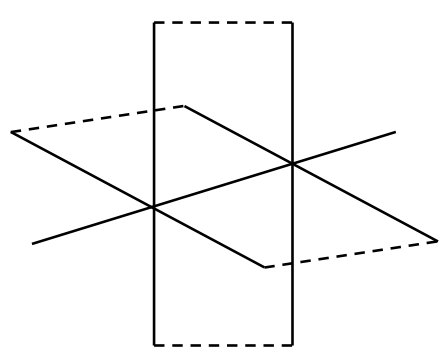

(c)

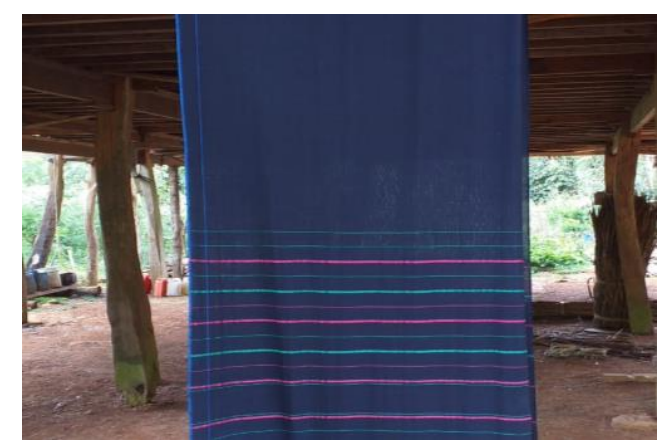

(b)

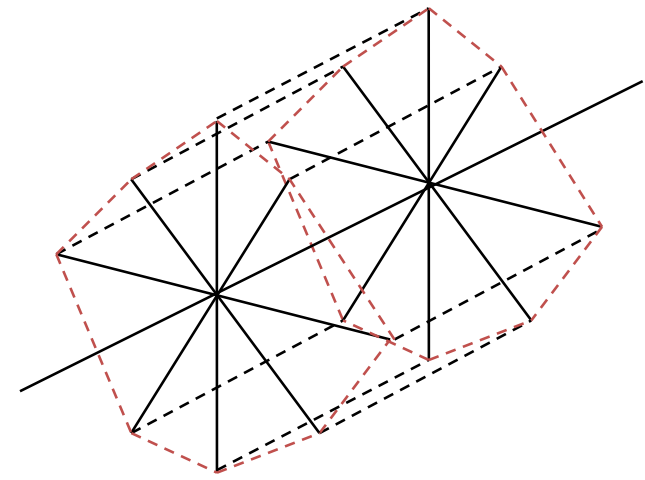

(d)

Figure 2. (a) Yarn spinning tool, (b) Ammatoa sarong motif in the form of parallel line objects, (c and d) Geometric abstraction of the yarn spinning tool

The other side of the Ammatoa indigenous people is that they do not use footwear because they believe that no one can obstruct humans from the land as their mother. Even including when building a house, the pillar of the house must be embedded in the ground, should not be grounded in stones or walls because it is believed to be breaking the relationship between humans and their mothers. The whole house of Ammatoa people is made of wood which has 16 to 20 poles with the same shape and material for each community member. Stage-shaped house with all using materials provided by nature, without using nails at all. The roof used is thatch made from palm leaf midribs. The walls of bamboo or wood slats are woven using certain patterns. Measurements are made using body parts such as lama' (span), rappa (fathoms), or using rattan with a certain length. Every house in the customary area faces west which is believed to be the origin of their ancestors. Ammatoa's indigenous knowledge about geometry, congruence, and harmony has been used to build sturdy houses. Correspondingly, artifacts in the form of geometric ornaments are suitable materials applied in mathematics learning (Verner et al., 2019). 


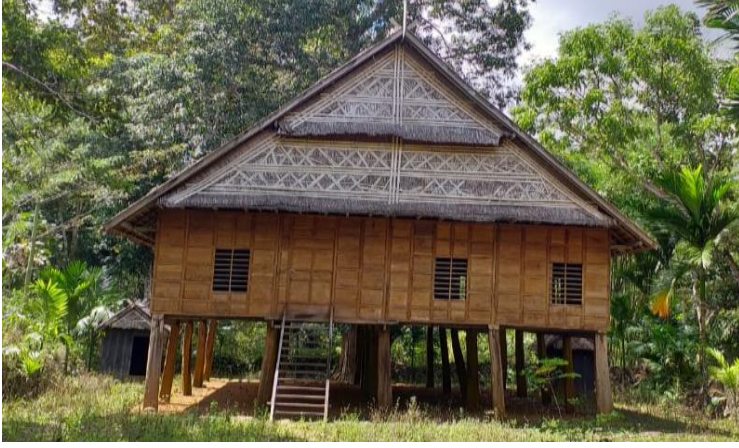

(a)

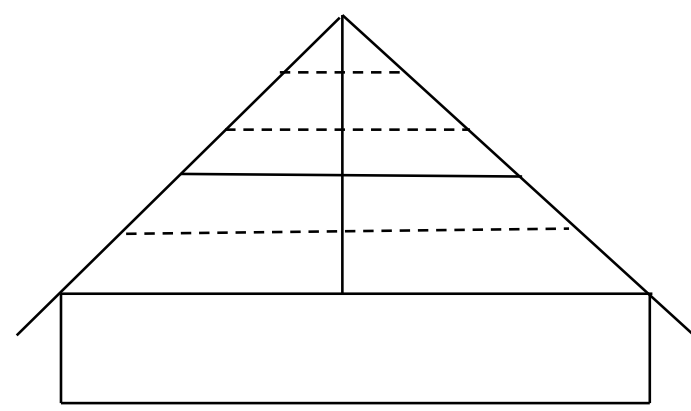

(b)

Figure 3. (a) Ammatoa traditional house, (b) Geometric construct of the Ammatoa traditional house

The Figure 3 illustrates the traditional house, Ammatoa. The space placement in the Ammatoa traditional house is unique because the kitchen is located at the front. Philosophically, the location of the kitchen in front of the house indicates that the Ammatoa people never hide food from their guests. There is no wall between the kitchen and living room. In general, the bedroom is positioned crosswise in an L-like shape. Each bedroom door uses a sliding model that makes space utilization ergonomic. Likewise windows, all use a sliding model with a square shape. At the top of the room, there is an attic called the para-para a place to keep agricultural products. The concept of space that is owned by the Ammatoa people shows the ability to spatial thinking without leaving the philosophical power that is deeply embedded in their culture.

Family in the Ammatoa community is very strong based on the philosophy of pacce (empathy). Customary rituals of community members such as death events or wedding parties will invite all indigenous people to gather and postpone their activities, including children who will go to school. Attending traditional events is a means of communicating and establishing a sense of kinship among the community, accompanied by giving a certain amount of money to people who are having hold events. Every money collected is recorded with the aim that when the person performs the event the reward will be greater. The Ammatoa people believe that all good things must be rewarded with the greater good. If the giving money follows a pattern of numbers, then the concept of arithmetic can be used. The concept of percentage and social arithmetic is another example of the relationship between these activities with mathematics.

Folklore is a cultural heritage of indigenous people which is closely related to the ability to think creatively, critically, and communicatively. The Ammatoa are familiar with many folklore called a'rupama (parables). A'rupama is a collection of folklore that has long been used to entertain the community and children. The story in a'rupama is delivered humorously but does not forget the essence of teaching, and the contemplation of life. Folklore is a cultural heritage that often involves an active thought process for its listeners (Fouze \& Amit, 2018b). In the Hausa community, folklore takes the form of a puzzle that motivates children to answer these questions using mathematical thinking (Waziri et al., 2010).

Mathematics learning can also depart from the context of traditional games (Fouze \& Amit, 2018b; Nkopodi \& Mosimege, 2009). Traditional games can enrich concepts and provide encouragement to students to learn mathematics more meaningful (Nkopodi \& Mosimege, 2009). Traditional games commonly played by 
children in Ammatoa people such as a'banga. The a'banga game has rules for getting all banga that is hazelnut seeds in a circle, one must remove the banga from the circle until it runs out. The position of all players is approximately 5 steps from the circle and plays with the launcher to get each chance. The first chance is given to the player who has the launcher banga farthest from the circle, each banga that is able to come out is the banga won. Here determining the starting position of the launcher is a decisive strategy for winning the game.

The above description shows the various cultural variations in the indigenous Ammatoa community having a connection with mathematics. Although in practice the Ammatoa community uses informal knowledge, there is a relation of these ideas and activities into a school mathematics domain. Contextual mathematics is an approach that can minimize the gap of initial knowledge possessed by students in their environment with formal knowledge taught in schools (Yee \& Bostic, 2014). Students can understand the importance of learning mathematics by identifying various knowledge that already exists in the community (Johnson, 2017). However, efforts are needed to ensure equitable pedagogical practices for students through teacher understanding of the culture of indigenous people (Gavarrete, 2015). Mathematical learning in cultural context requires teacher competence related to didactic aspects, understanding of material content, and the ability to elaborate the philosophy behind the culture (Verner et al., 2019).

Mathematics cannot be denied having a unique system in indigenous communities that should be considered in learning (Entremont, 2015; Fouze \& Amit, 2018a; Verner et al., 2019; Were, 2003). Furthermore, collaborative education is necessary to ensure students' access to school is not blocked by stigma walls (Nisser, 2017). Teachers need to foster a culture of the school environment that is humanist and allows students to develop all the potential thinking they have (Hunter et al., 2016). Instead, parents provide trust and support to the school to provide the broadest possible access to students. A better future can only be achieved by gaining knowledge and education.

\section{CONCLUSION}

Mathematics is the knowledge that has grown and has a relationship with human activities and culture, including indigenous people. Ammatoa indigenous people practice mathematics in the form of knowledge systems in the form of folklore and traditional measurement tools. The form of community activities in the form of crafts, traditional games, and rituals use various mathematical concepts. Cultural products (artifacts) such as houses and cutlery also contain mathematical elements that are very likely to be a starting point for learning in the classroom. The use of mathematics in a cultural context (ethnomathematics) is a form of contextualization of mathematics that is too formal in the national curriculum. Contextual ethnomathematics can be a means for indigenous people to take an interest in and obtain various reasons to study mathematics. However, efforts to use ethnomathematics can have broader impacts beyond pedagogical practices in the classroom. Students have greater opportunities to connect schools with their realworld situations. Closer relationships can arise from the active role of teachers, schools, parents, and indigenous communities in collaborative learning so that it leads to increased student participation in learning in the classroom.

IJEME, Vol. 5, No. 1, March 2021, 1-12. 


\section{REFERENCES}

Ary, D., Jacobs, L. C., \& Sorensen, C. (2010). Introduction to Research in Education. Belmont: Cengage Learning.

Ascher, M. (1995). Models and Maps from the Marshall Islands: A Case in Ethnomathematics. Historia Mathematica, 22, 347-370.

Ascher, M. (1997). Malagasy Sikidy: A Case in Ethnomathematics. Historia Mathematica, 24, 376-395.

Baxter, L. P., \& Meyers, N. M. (2019). Indigenous (and all) students' school attendance: Investigating data collection methods. Issues in Educational Research, 29(4), 1068-1088.

Darmayasa, J. B. (2018). Studi Etnografi Tentang Literasi Matematik dan Ethnomathematics Masyarakat Bali Mula. Bandung: Universitas Pendidikan Indonesia.

Entremont, Y. (2015). Linking mathematics, culture, and community. Procedia Social and Behavioral Sciences, 174, 2818-2824.

Fouze, A. Q., \& Amit, M. (2018a). On the Importance of an Ethnomathematical Curriculum in Mathematics Education. EURASIA Journal of Mathematics, Science and Technology Education, 14(2), 561-567.

Fouze, A. Q., \& Amit, M. (2018b). Development of Mathematical Thinking through Integration of Ethnomathematic Folklore Game in Math Instruction. EURASIA Journal of Mathematics, Science and Technology Education, 14(2), 617-630.

Gavarrete, M. E. (2015). The challenges of mathematics education for Indigenous teacher training training. Intercultural Education Journal, 26(4), 326-337.

Hunter, J., Hunter, R., Bills, T., Cheung, I., \& Hannant, B. (2016). Developing Equity for Pasifika Learners Within a New Zealand Context: Attending to Culture and Values. New Zealand Journal of Educational Studies, 51(2), 197-209.

Ismail, M. R., \& Ismail, H. (2010). Exploring Malay-Islamic Ethnomathematics: AlKhatib ' s Combinatoric Theory In 'Alam Al-Hussab And Raudah Al-Hussab. International Conference on Mathematics Education Research, 8, 735-744.

Johnson, J. (2017). A Topic Revisited : Students in the Republic of the Maldives Writing Contextual Word Problems. International Electronic Journal of Mathematics Education, 12(3), 549-559.

Khoroshikh, P. P., \& Sergievich, A. A. (2019). Fundamentals of Mathematical Knowledge in the Traditional Culture of Evenks. Journal of Language and Cultural Education, 7(1), 70-83.

Laurens, T., Ngilawayan, D., \& Pattiasina, J. (2019). Ethnomathematics Study of Islands Indigenous people in Maluku Province, Indonesia. Jurnal Pendidikan Progresif, 9(1), 113-122.

MOEC. (2017). UU Nomor 5 Tahun 2017 Tentang Pemajuan Kebudayaan. Jakarta: Indonesian Ministry of Education and Culture.

MOEC. (2018). Permendibud Nomor 20 Tahun 2018 Tentang Penguatan Pendidikan Karakter pada Satuan Pendidikan Formal. Jakarta: Indonesian Ministry of Education and Culture.

Moramay, M., \& Méndez, M. (2010). The vigesimal numerical system in the communities practices of the maya's culture. Procedia Social and Behavioral Sciences, 2, 3468-3471.

Nisser, D. V. A. (2017). Can collaborative consultation, based on communicative theory , promote an inclusive school culture? Issues in Educational Research, 27(4), 874891. 
Nkopodi, N., \& Mosimege, M. (2009). Incorporating the indigenous game of morabaraba in the learning of mathematics. South African Journal of Education, 29, 377-392.

Nur, A. S., Waluya, S. B., Rochmad, R., \& Wardono, W. (2020). Contextual learning with Ethnomathematics in enhancing the problem solving based on thinking levels. JRAMathEdu (Journal of Research and Advances in Mathematics Education), 5(3), 331-344.

Nutti, Y. J. (2016). Decolonizing Indigenous teaching: Renewing actions through a Critical Utopian Action Research framework. Action Research Journal, 10(1), 1-23.

Orey, D. C., \& Rosa, M. (2006). Ethnomathematics: Cultural Assertions and Challenges Towards Pedagogical Action. The Journal of Mathematics and Culture, 6(1), 57-78.

Owens, K. (2012). Identity and Ethnomathematics Projects in Papua New Guinea An Ecocultural Pedagogy of Mathematics. Proceedings of the 35th annual conference of the Mathematics Education Research Group of Australasia (pp. 586-593).

Rosa, M., \& Orey, D. C. (2018). The Anthropological Dimension on Ethnomodelling Research Based on Ethnomathematics and Modelling. Journal of Archaeology and Anthropology, 1(1), 1-8.

Sambu, A. H. (2016). Sejarah Kajang. Yogyakarta: Lingkar Media.

Verner, I., Massarwe, K., \& Bshouty, D. (2019). Development of competencies for teaching geometry through an ethnomathematical approach. Journal of Mathematical Behavior, 100708.

Waziri, M. Y., Saidu, I., \& Musa, H. (2010). A mathematical approach on solving Hausa Puzzles in Northern Nigeria. Procedia-Social and Behavioral Sciences, 8, 694-699.

Weldeana, H. N. (2016). Ethnomathematics in Ethiopia: Futile or Fertile for Mathematics Education? Momona Ethiopian Journal of Science (MEJS), 8(2), 146167.

Were, G. (2003). An Anthropological Approach to Mathematics Education. Journal of Material Culture, 8(1), 25-44.

Yee, S. P., \& Bostic, J. D. (2014). The Journal of Mathematical Behavior Developing a contextualization of students' mathematical problem solving. Journal of Mathematical Behavior, 36, 1-19. 